\title{
Satranç A Milli Oyuncularının Toplam ve Bölgesel Vücut Kompozisyonu Bileşenleri
}

\author{
Total and Regional Body Composition Components of National Chess Players
}

\author{
Selin Aktitiz ${ }^{1}$, Süleyman Bulut ${ }^{2}$, Muhammed Mustafa Atakan³ ${ }^{3}$ Yasemin Güzel $^{4}$, Ceren Işıl Atabey \\ Şükran Nazan Koşar ${ }^{6}$, Hüseyin Hüsrev Turnagöl ${ }^{7}$
}

Geliş tarihi/Received: 08.12.2020 • Kabul tarihi/Accepted: 03.08.2021

\section{ÖZET}

Amaç: Satranç oyununun karakteri gereği oyuncular gün içerisinde uzun süre (3-4 saat/gün) oturarak alıştırma yaptıklarından fiziksel aktivitelere katılımları sınırlanmaktadır. Bu durum satranç oyuncuları için sedanter yaşam tarzını arttırarak fazla kilo/obezite ve ilişkili kronik hastalıklar riskini artırabilir. Bu çalışmanın amacı, elit düzeydeki satranç oyuncularının toplam ve bölgesel vücut kompozisyonu bileşenlerinin beden kütle indeksi (BKİ), yaş ve cinsiyete göre eşleştirilmiş kontrollerle karşılaştırılmasıdır.

Bireyler ve Yöntem: Çalışmaya 12 A-Milli satranç oyuncusu (yaş: $24.9 \pm 5.9$ yıl; BKİ: $23.5 \pm 2.8 \mathrm{~kg} / \mathrm{m}^{2}$ ) ve 12 kontrol katılımcı (yaş: $24.6 \pm 1.6$ yıl; BKİ:23.5 $\pm 3.3 \mathrm{~kg} / \mathrm{m}^{2}$ ) alınmıştır. Vücut kompozisyonu, dual enerji x-ray absorbsiyometri cihazı ile ölçülmüştür. Satranç ve kontrol gruplarının karşılaştırılmasında bağımsız gruplarda t-test analizi kullanılmıştır.

Bulgular: Kontrol grubuna kıyasla satranç oyuncularının toplam yağ kütlesi, viseral yağ kütlesi ve yağ oranı daha yüksek; yağsız yumuşak doku kütlesi ve kemik kütlesi ise daha düşük bulunmuş olmakla beraber bu farklllıklar istatistiksel olarak önemli değildir ( $p>0.05$ ). Kadın satranç oyuncularının toplam yağ oranı kontrol grubununkine benzer ( $>0.05$ ), viseral yağ kütlesi ise daha düşüktür ( $\mathrm{p}=0.015)$. Erkek satranç oyuncuları, kontrol grubuna kıyasla daha düşük yağsız yumuşak doku ve daha yüksek yağ oranına sahip olmakla beraber istatistiksel olarak anlamlı fark bulunmamıştır ( $>0.05)$. Her iki cinsiyette de satranç oyuncularının bölgesel yağ oranları (kol, gövde, bacak, android, jinoid) kontrol grubundan daha yüksek bulunmakla beraber bu bulgu istatistiksel olarak önemli değildir ( $>0.05$ ). Vücut yağ ve kas düzeyi göstergeleri değerlendirildiğinde, erkek satranç oyuncuları kontrol grubuna kıyasla daha yüksek yağ kütlesi indeksi, daha düşük toplam ve apendiküler yağsız yumuşak doku kütlesi indekslerine sahip olmakla beraber bu farklılıklar istatistiksel olarak anlamlı bulunmamıştır (p>0.05). Kadın satranç sporcularında da yağ kütlesi indeksi ve apendiküler yağsız yumuşak doku kütlesi indeksi değerleri kontrol grubuyla benzer ( $p>0.05$ ) iken yağsız yumuşak doku kütlesi indeksi daha düşük bulunmuştur ( $\mathrm{p}=0.022)$.

1. Hacettepe Üniversitesi, Spor Bilimleri Fakültesi, Rekreasyon Bölümü, Egzersizde Beslenme ve Metabolizma Anabilim Dall, Ankara, Türkiye

(1) https://orcid.org/0000-0001-6781-8681

2. Hacettepe Üniversitesi, Spor Bilimleri Fakültesi, Rekreasyon Bölümü, Egzersizde Beslenme ve Metabolizma Anabilim Dall, Ankara, Türkiye

ㄴ https://orcid.org/0000-0001-6831-6608

3. Hacettepe Üniversitesi, Spor Bilimleri Fakültesi, Rekreasyon Bölümü, Egzersizde Beslenme ve Metabolizma Anabilim Dall, Ankara, Türkiye

○ https://orcid.org/0000-0003-3196-6345

4. Hacettepe Üniversitesi, Spor Bilimleri Fakültesi, Rekreasyon Bölümü, Egzersizde Beslenme ve Metabolizma Anabilim Dall, Ankara, Türkiye

(ㄱ https://orcid.org/0000-0003-1831-2371
5. Hacettepe Üniversitesi, Spor Bilimleri Fakültesi, Rekreasyon Bölümü, Egzersizde Beslenme ve Metabolizma Anabilim Dall, Ankara, Türkiye (i) https://orcid.org/0000-0002-2969-3854

6. Hacettepe Üniversitesi, Spor Bilimleri Fakültesi, Rekreasyon Bölümü, Egzersizde Beslenme ve Metabolizma Anabilim Dall, Ankara, Türkiye 으 https://orcid.org/0000-0002-4235-8364

7. İletişim/Correspondence: Hacettepe Üniversitesi, Spor Bilimleri Fakültesi, Rekreasyon Bölümü, Egzersizde Beslenme ve Metabolizma Anabilim Dalı, Ankara, Türkiye • E-posta: husrevturnagol@gmail.com

(1) https://orcid.org/0000-0001-6547-8839 
Sonuç: Bu çalışmada değerlendirilen A milli satranç oyuncularının toplam ve bölgesel vücut kompozisyonu bileşenleri BKİ, yaş ve cinsiyet yönünden eşdeğer kontrollerle benzerdir.

Anahtar kelimeler: Satranç, dual enerji x-ray absorbsiyometri, vücut kompozisyonu, apendiküler kas kütlesi, yağ kütlesi indeksi

\section{ABSTRACT}

Aim: Due to the nature of the chess game, chess players practice while sitting for a long time (3-4 hours/day) during the day that limits their participation in physical activities. This may increase the risk of overweight/obesity and associated chronic diseases by increasing the sedentary time for chess players. Thus, the aim of this study is to compare the total and regional body composition components of elite chess players with body mass index (BMI), age and gender-matched controls.

Subjects and Method: Twelve national chess players (age: $24.9 \pm 5.9$ years; BMI: $23.5 \pm 2.8 \mathrm{~kg} / \mathrm{m}^{2}$ ) and 12 control participants (age: $24.6 \pm 1.6$ years; BMI: $23.5 \pm 3.3 \mathrm{~kg} / \mathrm{m}^{2}$ ) were included in the study. Body composition was measured by dual energy x-ray absorptiometry method. Independent t-test was used to compare the groups.

Results: Although the chess players had higher total fat mass, visceral fat mass and fat percentages and lower lean soft tissue mass and bone mass compared to the controls, the differences were not statistically significant ( $p>0.05)$. In females, chess players had similar total body fat percentage $(p>0.05)$ and lower visceral fat mass than the controls $(p=0.015)$. Male chess players had lower lean soft tissue and higher body fat percentage compared to the control group however, these were not statistically significant ( $\mathrm{p}>0.05$ ). Although the regional fat percentages (arm, trunk, leg, android, gynoid) of female and male chess players were higher than those of the control group, the differences were not statistically significant ( $p>0.05)$. Concerning the body fatness and muscularity indices, male chess players had higher fat mass index, lower total and appendicular lean soft tissue mass index compared to the control group, but the differences were not statistically significant ( $>0.05$ ). Fat mass index and appendicular lean soft tissue mass index values in female chess players were similar to those of control group ( $p>0.05$ ), while lean soft tissue mass index was found to be lower $(\mathrm{p}=0.022)$.

Conclusion: The total and regional body composition of elite chess players were similar with controls.

Keywords: Chess, dual energy x-ray absorptiometry, body composition, appendicular muscle mass, fat mass index

\section{GíRiş}

Satranç; iki oyuncunun 64 kareden oluşan bir tahta üzerinde siyah ve beyaz taşları belirlenmiş kurallar doğrultusunda hareket ettirdiği, zihinsel becerileri geliştiren bir strateji oyunudur (1). Satranç oyunu oldukça uzun sürebilmektedir. Örneğin Dünya Satranç Şampiyonası kurallarına göre, zaman kontrolü için her oyunda ilk 40 hamle 100 dakika, sonraki 20 hamle 50 dakika içinde gerçekleştirilmeli ve oyunun geri kalanı için 15 dakika ve her hamle için 30 saniye eklenmelidir (1). Performansa dayalı olması sebebiyle satranç, bir spor olarak değerlendirilmektedir (2). Ancak diğer spor branşlarının aksine, satranç oyuncuları gerek müsabakalar gerek gün içerisindeki alıştırmalar sırasında uzun süre (3-4 saat/gün) oturduklarından dolayı fiziksel aktivitelere katılımları sinırlı olabilmektedir (3). Sinırlı fiziksel aktivitenin yanında satranç oyuncularının, yeterli ve dengeli beslenme alışkanlıklarına sahip olmadıkları da saptanmıştır (4). Fiziksel inaktivitenin ve kötü beslenme alışkanlıklarının vücut kompozisyonunu olumsuz etkilediği ve beraberinde kalp-damar hastalıkları, diyabet ve kanser gibi birçok sağlık sorununa yol açtığı bilinmektedir (5-7).

$\mathrm{Bu}$ nedenle vücut kompozisyonunun takibi, bireyin uzun dönem beslenme ve sağlık durumu hakkında önemli bilgiler vermektedir (7). Hidrostatik tartı, biyoelektrik impedans analizörü, BOD POD, Dual enerji x ray absorbsiyometri cihazı (DXA) gibi farklı vücut kompozisyonu ölçüm yöntemleri olmakla 
birlikte (8), bu yöntemlerden DXA altın standart olarak kabul edilmektedir (9). DXA ile vücut kompozisyonu hem tüm vücut hem bölgesel olarak; kemik, yağ ve yağsız doku olmak üzere üç bileşenli olarak incelenebilmektedir (7). DXA aynı zamanda bir diğer sağlık belirteci olan kemik mineral yoğunluğunun değerlendirilmesinde de güvenilir bir yöntemdir $(10,11)$. DXA, özellikle kol ve bacaklarda kas kütlesinin bir göstergesi olarak kabul edilen yağsız yumuşak doku (YYD) kütlesinin değerlendirilmesine de olanak sağlamaktadır. Girişimsel olmayan bir yöntem olması, tüm taramanın 5-10 dakika içerisinde tamamlanması (12), radyasyon düzeyinin düşük (13) ve ölçüm hassasiyetinin yüksek olması DXA yönteminin avantajlarındandır. Sporcuların değerlendirilmesinde kullanılabilmesine rağmen (14) satranç sporcularının vücut kompozisyonunun DXA veya diğer yöntemlerle değerlendirildiği bir çalışmaya rastlanılmamıştır.

Oysaki satranç oyuncularınin antrenmanlar nedeniyle uzun süre oturmaları sebebiyle yaşıtları ile karşılaştırıldığında; daha yüksek yağ oranı, viseral yağ kütlesi ve yağ kütle indeksine, diğer taraftan daha düşük kas kütlesi ve kas kütle indeksine sahip olabilecekleri düşünülmektedir. $\mathrm{Bu}$ durum birçok sağlık riskini beraberinde getirebilir. Vücut ağırlığı obezitenin önemli bir belirteci olmakla birlikte normal vücut ağırlığında ancak yüksek yağ kütlesi ve düşük kas kütlesine sahip bireyler de "normal kiloda, metabolik olarak obez bireyler" şeklinde sinıflandırılmakta ve bu grup da metabolik disregülasyon, sistemik inflamasyon gibi obeziteye bağlı birçok riskle karşı karşıya kalmaktadır (15). Yüksek viseral yağ kütlesinin de karaciğere iletilen yüksek yağ asidinin ana kaynağı olması ve daha patojenik sitokin profiline sahip olması gibi nedenlerle insülin direnci, diyabet ve kardiyovasküler hastalıklar gibi metabolik birçok hastalıkla ilişkili olduğu bilinmektedir (16,17). Vücut yağ yüzdesi, viseral yağ kütlesi gibi parametrelerin yanı sıra yağ ve kas kütle indeksi değerleri de beden kütle indeksine (BKİ) kıyasla daha spesifik değerlendirmelere olanak sağlamaktadır (18). Bu nedenlerle vücut kompozisyonunun ayrıntılı değerlendirilmesi, satranç da dahil olmak üzere birçok spesifik popülasyona özgü tanımlayıcı bilgilerin oluşturulması açısından önemlidir. Bu çerçevede, bu çalışmanın amacı elit düzeydeki satranç oyuncularının toplam ve bölgesel vücut kompozisyonu bileşenlerini BKİ, yaş ve cinsiyete göre eşleştirilmiş kontrollerle karşılaştırmak ve satranç oyuncularının vücut kompozisyonuna ilişkin tanımlayıcı veri sağlamaktır.

\section{BİREYLER VE YÖNTEM}

\section{Araştırma Grubu}

$\mathrm{Bu}$ araştırmaya yetişkin elit düzeyde satranç oynayan 8 erkek ve 4 kadın olmak üzere 12 milli satranç

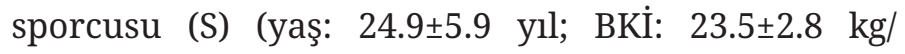
$\mathrm{m}^{2}$ ) ve kontrol grubunu (K) oluşturmak üzere yaş, cinsiyet ve BKİ bakımından satranç grubuna eş değer 12 birey (yaş: $24.6 \pm 1.6$ yll; BKİ: $23.5 \pm 3.3 \mathrm{~kg} / \mathrm{m}^{2}$ ) katılmıştır. Kontrol grubu, sporcu olmayan sağlıklı kişiler arasından; satranç grubundaki her oyuncuya yaş, cinsiyet ve BKİ yönünden benzer olan bir birey seçilerek oluşturulmuştur. Tüm katılımcılardan, çalışmaya katılmadan önce yazılı onam alınmış ve çalışma Helsinki Bildirgesi'ne uygun olarak yapılmıştır. Bu çalışma için Hacettepe Üniversitesi Girişimsel Olmayan Etik Kurulundan onay alınmıştır (GO 20/1046).

\section{Araştırma Yöntemi}

Vücut kompozisyonu, dual enerji x-ray absorbsiyometri (DXA, Lunar Prodigy Pro, GE Health Care, Madison Wisconsin, US) cihazı ile ölçülmüş ve aynı firmanın yazılımı (enCORE ${ }^{\mathrm{TM}}$ v.14.10.022) kullanılarak analiz edilmiştir. Laboratuvarın DXA ölçüm varyasyon katsayısı (VK) bağımsız bir grup üzerinde belirlendikten sonra ( $n=33$; vücut ağırlığı: $\% 0.18$, kas kütlesi: \%0.4, yağ kütlesi: \%2.09, kemik mineral yoğunluğu: \%0.4) araştırmaya katılan katılımcıların vücut kompozisyonu ölçümleri yapılmıştır.

Katılımcılar ölçümden en az 8 saat önce besin ve sıvı alımını sonlandırarak, sabah saatlerinde laboratuvara 
gelmiştir. DXA ölçümü öncesi katılımcıların boy uzunlukları boy ölçer (Holtain stadiometer, UK), vücut ağırlıkları ise dijital baskül (Tanita SC330, Japonya) ile belirlenmiştir. Tüm seyreltici maddelerin (kemer, metal düğme, vb.) ölçüm alanından çıkarıldığından emin olunduktan sonra ölçüm prosedürlerine başlanmıştır. Katılımcı ayakkabıları çıkarıldıktan sonra tarama sehpasındaki orta çizgi referans alınarak sehpanın ortasına gelecek şekilde yerleştirilmiştir. Katılımcının ellerinin, vücudunun her iki tarafinda başparmakları yukarı, avuçları bacaklarına dönük; kollarının da gövde boyunca uzanır halde olması sağlanmıştır. Ölçüm hassasiyeti için ellerin bacaklara dokunmaması ve kollar ile torso arasında küçük bir hava boşluğu ( 1 cm) bulunması sağlanmıştır. Katılımcının kollarının, sehpa yüzeyindeki tarama alanı çizgileri içerisinde kaldığı doğrulanmış, ayrıca başının, sehpa yüzeyindeki yatay çizginin $3 \mathrm{~cm}$ altında olduğundan emin olunmuştur. Ölçüm sırasında hareketi önlemek için, velcro kayışları kullanılarak katılımcının dizleri ve ayakları sabitlenerek Encore yazılımı (GE/Lunar) ile ölçüm gerçekleştirilmiştir. Encore yazılımındaki görüntünün doğru olduğundan emin olmak için ölçüm sırasında bilgisayardaki katılımcı görüntüsü izlenmiş ve görüntünün ölçülen kişinin tüm vücudunu gösterir şekilde olmasına azami hassasiyet gösterilmiştir. Başın, ayakların ve kolların görüntüde yer aldığından emin olunmuştur (19). Toplam yağ kütlesi, vücut yağ oranı (VYO), yağsız vücut ağırlığı (YVA), yağsız yumuşak doku (YYD) oranı ve kemik kütlesinin yanı sıra bölgesel (kol, bacak ve gövde) yağ kütlesi ve yağsız yumuşak doku kütlesi değerleri kaydedilmiştir. Yağ kütle indeksi, toplam ve apendiküler YYD indeksi değerleri ise sırasıyla toplam veya apendiküler bölge için yağ ya da YYD kütlesinin (kg), boy uzunluğunun karesine $\left(\mathrm{m}^{2}\right)$ bölünmesi ile hesaplanmıştır (20).

Apendiküler YYD indeksi $=\left(\mathrm{YYD}_{\text {Kollar }}[\mathrm{kg}]+\mathrm{YYD}_{\text {Bacaklar }}\right.$ [kg]) / Boy uzunluğu ${ }^{2}\left[\mathrm{~m}^{2}\right]$ (20).

Tüm ölçümler DXA kullanım sertifikası olan bir uzman tarafından gerçekleştirilmiş ve her ölçüm gününün sabahında DXA cihazının kalibrasyonu yapılmıştır.

\section{Verilerin İstatistiksel Değerlendirilmesi}

Satranç grubu ile kontrol grubunun vücut kompozisyonu değişkenlerinin karşılaştırılmasında Bağımsız Gruplarda $\mathrm{t}$ Test Analizi kullanılmıştır. İstatistiksel anlamlılık düzeyi $\mathrm{p}<0.05$ olarak kabul edilmiştir. Verilerin istatistiksel analizi SPSS 23.0 programı kullanılarak yapılmıştır.

\section{BULGULAR}

Satranç ve kontrol grubunun vücut ağırlığı ve BKI değerleri benzer bulunmuştur. Kontrol grubuna kıyasla satranç grubundaki bireylerin toplam yağ kütlesi (S: $21.84 \pm 7.89 \mathrm{~kg}$; K: $19.72 \pm 5.07 \mathrm{~kg}$ ) ve viseral

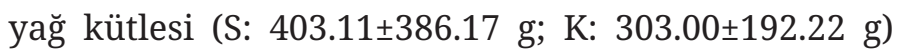
daha fazla; yağsız yumuşak doku kütlesi (lean mass) (S: $44.89 \pm 11.22 \mathrm{~kg}$; K: $48.96 \pm 12.89 \mathrm{~kg}$ ) ve kemik kütlesi (S: $2.45 \pm 0.49 \mathrm{~kg} ; \mathrm{K}: 2.71 \pm 0.55 \mathrm{~kg}$ ) daha az olmakla beraber bu farklılıklar istatistiksel olarak anlamlı değildir (Tablo 1; p>0.05). Kadın satranç oyuncularının viseral yağ kütlesi kontrol grubundaki kadınlardan daha düşük bulunmuştur (Tablo 1; p=0.015).

Satranç grubundaki kadınların toplam yağ oranları kontrol grubu ile benzerdir (S: \%37.23 \pm 3.63 , K: \%36.52 \pm 5.22 ; p>0.05) (Grafik 1A). Satranç grubundaki erkekler kontrol grubuna göre istatiksel olarak önemli olmasa da daha düşük yağsız yumuşak doku

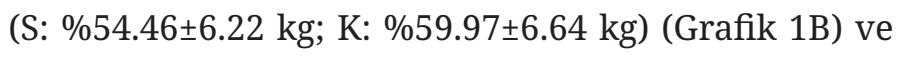
daha yüksek yağ oranına sahiptir (S: \%28.66 \pm 7.09 ; K: \%24.29 $\pm 6.13, \mathrm{p}>0.05$ ) (Grafik 1A). Tüm katılımcıların (kadın ve erkek) değerleri incelendiğinde ise, satranç grubunun yağ oranının kontrol grubuna göre daha yüksek (S: \%31.52 \pm 7.31 ; K: \%28.37 \pm 8.23 ) (Grafik $1 \mathrm{~A})$, yağsız yumuşak doku oranının ise daha düşük

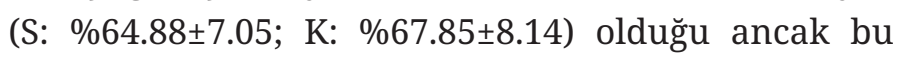
farklılıkların istatistiksel olarak önemli olmadığı anlaşılmaktadır ( $p>0.05$ ) (Grafik 1B).

Bölgesel yağ oranları incelendiğinde, satranç grubundaki kadın ve erkeklerin, kol, gövde ve bacak yağ oranlarının kontrol grubuna kıyasla daha fazla olduğu ancak bu farklılığın istatistiksel olarak önemli olmadığı belirlenmiştir (Tablo 2; p>0.05). Android ve jinoid bölgedeki yağ oranları karşılaştırıldığında 
Tablo 1. Katılımclların tüm vücut kompozisyonu göstergelerinin ortalama ve standart sapma değerleri

\begin{tabular}{|c|c|c|c|c|c|c|c|}
\hline & & \multicolumn{2}{|c|}{ Satranç $(n=12)$} & \multicolumn{2}{|c|}{ Kontrol $(n=12)$} & \multirow[b]{2}{*}{$\mathbf{t}$} & \multirow[b]{2}{*}{$\mathbf{p}$} \\
\hline & & $\overline{\mathbf{X}}$ & SS & $\overline{\mathbf{X}}$ & SS & & \\
\hline \multirow[t]{3}{*}{ Vücut Ağırlığı (kg) } & Kadın & 52.73 & 5.61 & 54.9 & 3.83 & -0.640 & 0.572 \\
\hline & Erkek & 76.93 & 13.51 & 78.76 & 8.36 & -0.327 & 0.218 \\
\hline & Toplam & 68.86 & 16.33 & 70.81 & 13.66 & -0.317 & 0.431 \\
\hline \multirow[t]{3}{*}{ Boy Uzunluğu (cm) } & Kadın & 157.95 & 3.11 & 161.13 & 4.01 & -1.250 & 0.537 \\
\hline & Erkek & 176.10 & 6.61 & 179.19 & 4.41 & -1.099 & 0.10 \\
\hline & Toplam & 170.05 & 10.50 & 173.17 & 9.79 & -0.752 & 0.931 \\
\hline \multirow[t]{3}{*}{ BKİ $\left(\mathbf{k g} / \mathbf{m}^{2}\right)$} & Kadın & 21.19 & 2.73 & 21.18 & 1.78 & 0.006 & 0.353 \\
\hline & Erkek & 24.78 & 3.80 & 24.54 & 2.56 & 0.146 & 0.463 \\
\hline & Toplam & 23.50 & 2.79 & 23.42 & 3.25 & 0.119 & 0.270 \\
\hline \multirow[t]{3}{*}{ DXA Vücut Kütlesi (kg) } & Kadın & 52.98 & 5.66 & 55.38 & 3.86 & -0.701 & 0.549 \\
\hline & Erkek & 77.29 & 13.52 & 79.39 & 8.48 & -0.372 & 0.230 \\
\hline & Toplam & 69.18 & 16.38 & 71.38 & 13.77 & -0.356 & 0.437 \\
\hline \multirow[t]{3}{*}{ Yağ Kütlesi (kg) } & Kadın & 19.86 & 3.98 & 20.33 & 3.96 & -0.166 & 0.902 \\
\hline & Erkek & 22.82 & 9.36 & 19.41 & 5.78 & 0.877 & 0.483 \\
\hline & Toplam & 21.84 & 7.89 & 19.72 & 5.07 & 0.783 & 0.403 \\
\hline \multirow{3}{*}{$\begin{array}{l}\text { Yağsız Yumuşak Doku } \\
\text { Kütlesi (kg) }\end{array}$} & Kadın & 31.21 & 1.92 & 33.01 & 2.28 & -1.208 & 0.981 \\
\hline & Erkek & 51.73 & 5.99 & 56.93 & 6.40 & -1.677 & 0.623 \\
\hline & Toplam & 44.89 & 11.22 & 48.96 & 12.89 & -0.824 & 0.593 \\
\hline \multirow[t]{3}{*}{ Viseral Yağ Kütlesi (g) } & Kadın & 192.50 & 22.29 & 254.00 & 129.60 & -0.935 & $0.015^{*}$ \\
\hline & Erkek & 571.60 & 466.94 & 327.50 & 220.92 & 1.289 & 0.191 \\
\hline & Toplam & 403.11 & 386.17 & 303.00 & 192.22 & 0.782 & 0.125 \\
\hline \multirow[t]{3}{*}{ Kemik Kütlesi (kg) } & Kadın & 1.91 & 0.18 & 2.05 & 0.11 & -1.356 & 0.391 \\
\hline & Erkek & 2.72 & 0.33 & 3.04 & 0.31 & -1.968 & 0.914 \\
\hline & Toplam & 2.45 & 0.49 & 2.71 & 0.55 & -1.214 & 0.680 \\
\hline
\end{tabular}

BKİ: Beden Kütle İndeksi, *: $p<0.05$
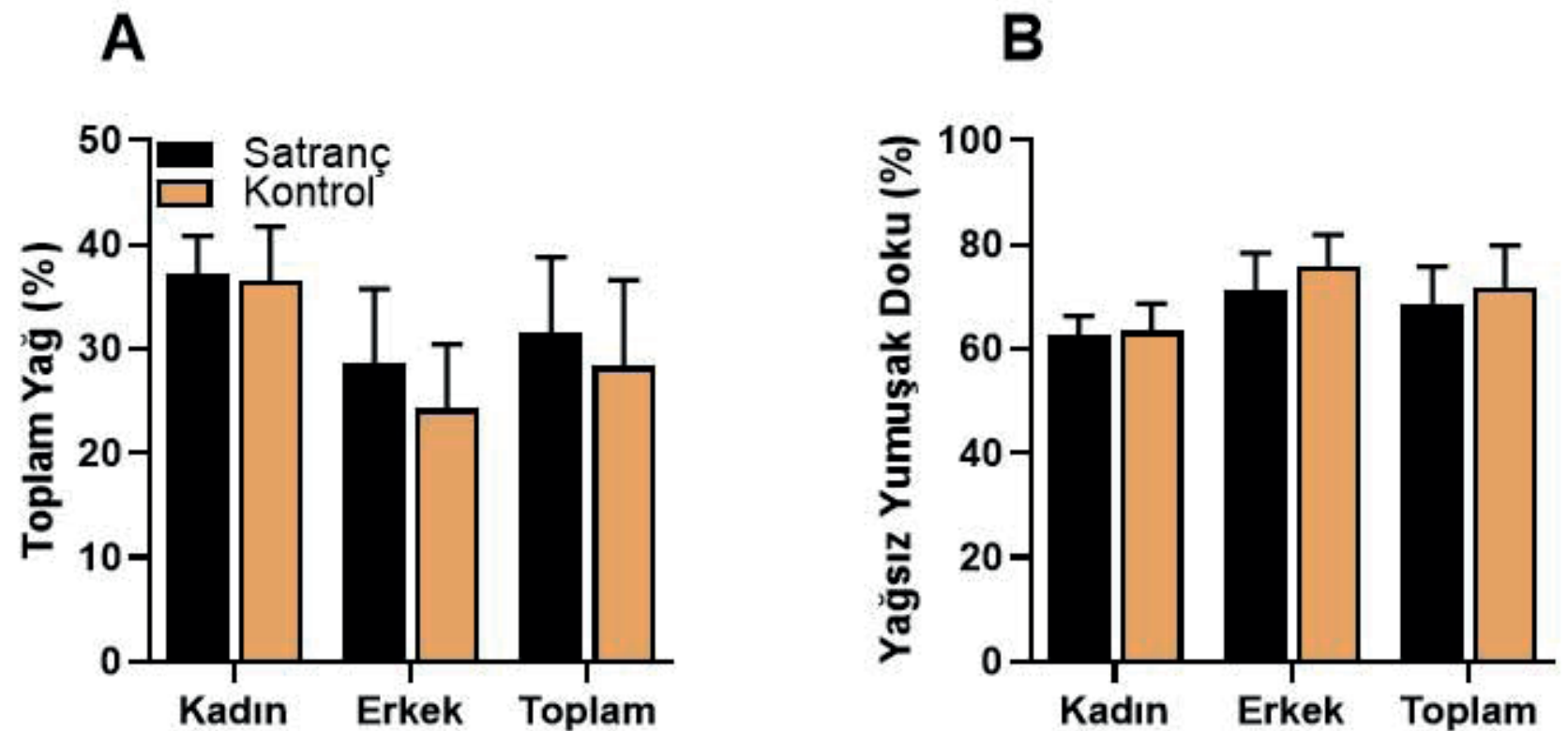

Grafik 1. Toplam yağ (A) ve yağsız yumuşak doku (B) oranlarının karşılaştırılması 
Tablo 2. Bölgesel ve tüm vücut yağ oranlarının (\%) ortalama ve standart sapma değerleri

\begin{tabular}{|c|c|c|c|c|c|c|c|}
\hline \multirow{2}{*}{ Vücut bölgesi } & & \multicolumn{2}{|c|}{ Satranç $(n=12)$} & \multicolumn{2}{|c|}{ Kontrol $(n=12)$} & \multirow[b]{2}{*}{$\mathbf{t}$} & \multirow[b]{2}{*}{$\mathbf{p}$} \\
\hline & & $\overline{\mathbf{x}}$ & SS & $\overline{\mathbf{x}}$ & SS & & \\
\hline \multirow[t]{3}{*}{ Gövde } & Kadın & 37.00 & 3.52 & 36.08 & 7.49 & 0.224 & 0.244 \\
\hline & Erkek & 29.36 & 10.35 & 23.95 & 6.90 & 1.244 & 0.450 \\
\hline & Toplam & 31.90 & 9.26 & 27.99 & 8.90 & 1.057 & 0.900 \\
\hline \multirow[t]{3}{*}{ Kollar } & Kadın & 37.83 & 3.82 & 39.60 & 5.01 & -0.564 & 0.708 \\
\hline & Erkek & 24.66 & 5.63 & 23.20 & 6.21 & 0.494 & 0.998 \\
\hline & Toplam & 29.05 & 8.13 & 28.67 & 9.83 & 0.104 & 0.742 \\
\hline \multirow[t]{3}{*}{ Bacaklar } & Kadın & 41.23 & 4.44 & 39.75 & 3.41 & 0.526 & 0.620 \\
\hline & Erkek & 30.24 & 4.77 & 25.89 & 6.90 & 1.467 & 0.387 \\
\hline & Toplam & 33.90 & 7.01 & 30.51 & 8.95 & 1.034 & 0.573 \\
\hline \multirow[t]{3}{*}{ Android } & Kadın & 37.98 & 4.81 & 36.55 & 9.54 & 0.267 & 0.338 \\
\hline & Erkek & 30.19 & 13.08 & 24.76 & 7.70 & 1.011 & 0.315 \\
\hline & Toplam & 32.78 & 11.40 & 28.69 & 9.81 & 0.943 & 0.705 \\
\hline \multirow[t]{3}{*}{ Jinoid } & Kadın & 44.38 & 4.94 & 42.93 & 5.64 & 0.387 & 0.585 \\
\hline & Erkek & 30.54 & 6.38 & 25.68 & 6.89 & 1.466 & 0.996 \\
\hline & Toplam & 35.15 & 8.88 & 31.43 & 10.54 & 0.936 & 0.706 \\
\hline \multirow[t]{3}{*}{ Toplam } & Kadın & 37.23 & 3.63 & 36.53 & 5.22 & 0.220 & 0.559 \\
\hline & Erkek & 28.66 & 7.10 & 24.29 & 6.13 & 1.319 & 0.805 \\
\hline & Toplam & 31.52 & 7.31 & 28.37 & 8.23 & 0.991 & 0.963 \\
\hline
\end{tabular}

da istatistiksel olarak önemli olmamasına rağmen satranç grubu daha yüksek android ve jinoid yağ oranlarma sahiptir ve bu durum erkeklerde daha belirgindir (Android, S: \%30.19 \pm 13.08 , K: \%24.76 \pm 7.7 ; Jinoid, S: \%30.54 $\pm 6.38 \mathrm{~K}: \% 25.68 \pm 6.89$; p>0.05) (Tablo 2).

Grafik2'de sunulan vücutyağ ve kas düzeyigöstergeleri değerlendirildiğinde, erkek satranç sporcularının, kontrol grubundan daha yüksek yağ kütlesi indeksi

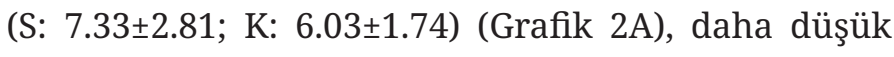
toplam yağsız yumuşak doku kütlesi indeksi (S:

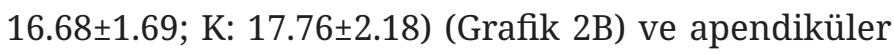
yağsız yumuşak doku kütlesi indeksine (S: 7.8 \pm 1.0 ; K: 8.30ะ1.26) (Grafik 2C) sahip olduğu; ancak bu farkın istatistiksel olarak önemli olmadığı anlaşılmaktadır (p>0.05). Kadın satranç sporcularında da yağ kütlesi

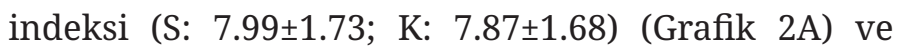
apendiküler yağsız yumuşak doku kütlesi indeksi
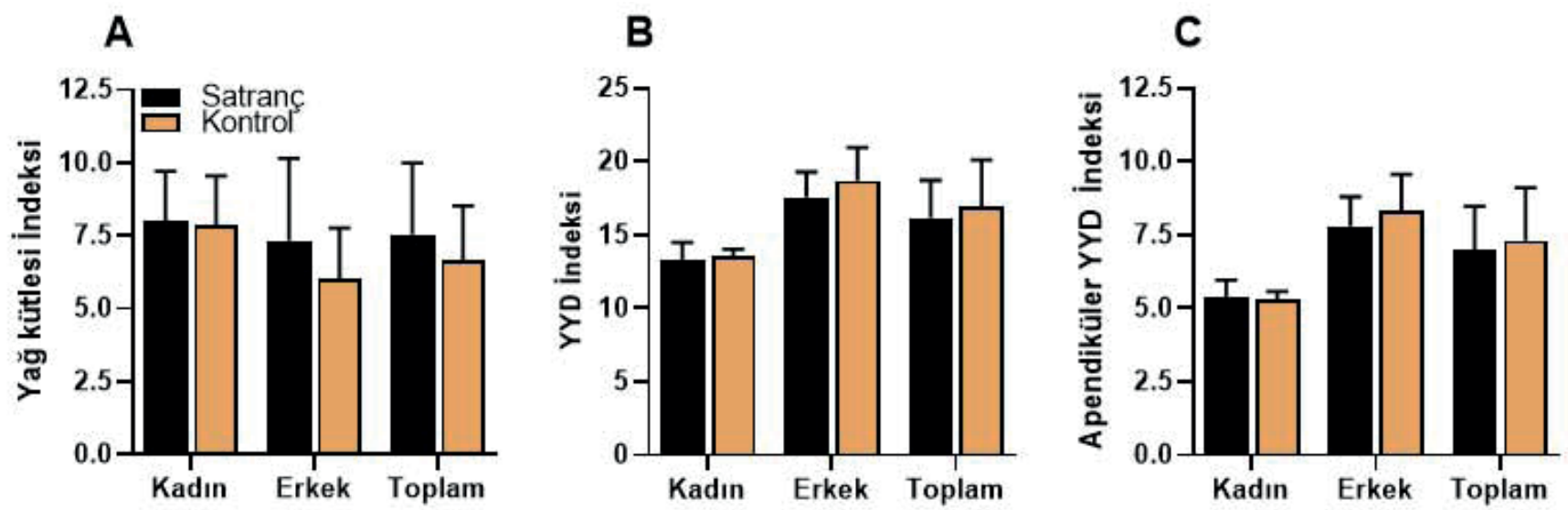

Grafik 2. Yağ kütlesi indeksi (A), yağsız yumuşak doku (YYD) kütlesi indeksi (B) ve apendiküler yağsız yumuşak doku kütlesi (C) indekslerinin karşılaştırılması 
(S: 5.36 \pm 0.60 ; K: 5.27 \pm 0.31 ) (Grafik 2C) değerleri kontrol grubuyla benzerdir $(p>0.05)$. Kadın satranç oyuncularının yağsız yumuşak doku kütlesi indeksi ise kontrol grubuyla karşılaştırıldığında istatiksel olarak daha düşük bulunmuştur (S: 12.53ะ1.14; K: $12.7 \pm 0.55 ; p=0.022)$ (Grafik 2B).

\section{TARTIŞMA}

$\mathrm{Bu}$ çalışmada uzun süre oturarak gerçekleştirilen antrenmanlar nedeniyle fiziksel aktivite düzeyi yetersiz olabilen A Milli satranç oyuncularının vücut kompozisyonları; yaş, cinsiyet ve BKİ bakımından eşleştirilmiş kontrol grubu ile karşılaştırılmıştır. $\mathrm{Bu}$ çalışma ulusal ve uluslararası literatürde satranç sporcularının vücut kompozisyonunun değerlendirildiği ilk çalışmadır. Çalışma kapsamında cinsiyetten bağımsız olarak satranç oyuncuları ile kontrol grubunun değerlerinin karşılaştırılması hedeflenmiştir ancak vücut kompozisyonunun cinsiyetler arası değişiklik göstermesi sebebiyle tüm değerler her iki cinsiyet için ayrı ayrı ve toplam olarak sunulmuştur. Çalışmanın bulguları değerlendirildiğinde hem kadın hem erkek satranç oyuncularının yüksek yağ ve düşük yağsız yumuşak doku oranına sahip olduğu, ancak kontrol grubunun değerleriyle de benzerlik gösterdiği belirlenmiştir (Grafik 1).

$\mathrm{Bu}$ çalışmadaki satranç oyuncularının toplam vücut yağ oranları, erkeklerde \%28.7 iken, kadınlarda \%37.2'dir (Grafik 1). Bu değerler 20-40 yaş arası yetişkin bireyler için önerilen DXA referans değerlerinin oldukça üzerindedir (Avrupalılar için Erkek: \%8-20; Kadın: \%21-33; Asyalılar için Erkek: \%13-23; Kadın: \%25-35) (21). Literatürde Türk popülasyonunun DXA yöntemiyle vücut kompozisyonunu değerlendiren bir çalışmaya rastlanılmamıştır. Ancak benzer diğer popülasyonlar incelendiğinde; Asyalı (Kadın: \%32.6; Erkek: \%21.6 (22), Çinli (Kadın: \%32.6; Erkek: \%21.6) (23) ve Avrupalı bireylerin (Kadın: \%34.0; Erkek: \%25.5) (24) toplam yağ oranı bu çalışmadaki satranç oyuncularına kıyasla daha düşüktür.

Kas kütlesi ile deri, tendon ve bağ dokunun bileşiminden oluşan ve kas kütlesinin göstergesi olarak değerlendirilen yağsız yumuşak doku oranları (25) değerlendirildiğinde ise satranç oyuncularının toplam yağsız yumuşak doku oranları (Kadın: \%58.9; Erkek: \%66.9; Grafik 1), benzer yaş ve BKİye sahip İspanyol bireylerle (Kadın: \%56.1; Erkek: \%63.3) benzerlik göstermektedir (26). Ancak bu değerler önerilen yağsız yumuşak doku yüzdesi referans değerinin (Erkek: \%73) altındadır (25). Avusturalyalı 20-29 yaş arası bireylerin toplam yağsız yumuşak doku kütlesi (Kadın: 41.2 kg; Erkek: 59.5 kg) (27), bu çalışmadaki satranç oyuncularından (Kadın: $31.2 \mathrm{~kg}$; Erkek: $51.7 \mathrm{~kg}$ ) daha fazladır.

Viseral yağ kütlesi incelendiğinde ise satranç oyuncularının (Kadın: 191.5 g; Erkek: 572.6 g) normal BKİye sahip bireylerden (Kadın: 187 g; Erkek: 474 g) (28) daha fazla; 20-30 yaş arasındaki Avrupalı erkek bireylerle (542.3 g) benzer, kadın bireylerden (257.8 g) ise daha az viseral yağ kütlesine sahip oldukları bulunmuştur (17). Nitekim 18-30 yaş arası genç yetişkinler için referans viseral yağ değeriyle karşılaştırıldığında da erkek satranç oyuncularının viseral yağ kütlesi referans değerin (424.6 g) üzerinde; kadın oyuncuların ise referans değerin (235.6 g) altındadır (29).

Bölgesel vücut yağ oranları incelendiğinde; satranç oyuncularının gövde yağ oranları \%31.9 olup (Tablo 2) bu değer İranlı bireylerin gövde yağ oranından (\%21.8) daha yüksektir (30). Bir başka çalışmada da (31) sporcu olmayan bireylerde gövde yağ oranı \%20.7 iken, sporcularda bu oran daha da düşük bulunmuştur (\%16.2). Aynı çalışmadaki benzer yaş ve BKİye sahip sporcu olmayan bireylerin kol (\%17.2) ve bacak yağ oranı da (\%19.2) (31) bu çalışmadaki erkek satranç oyuncularının kol (\%25) ve bacak yağ oranından (\%29) daha azdır (Tablo 2). Ayrıca çalışmamızdaki kadın satranç oyuncularının jinoid bölgedeki yağ oranlarının android bölgedeki yağ oranlarından daha yüksek, erkeklerin ise benzer oranlara sahip olduğu görülmektedir (Tablo 2). Her iki bölgede de düşük yağ oranı önerilmekle birlikte, android bölge yağı daha yüksek bireylerde kronik hastalık riskinin arttığı bilindiğinden $(32,33)$ kadın satranç oyuncularının yağ dokusu dağılımının daha sağlıklı olduğu değerlendirilebilir. 
Obezitenin değerlendirilmesinde kullanılan bir diğer parametre ise yağ kütlesi indeksidir (YKI). DXA analizi sonucu yağ kütlesi indeksi için erkeklerde 3-6 kg/m², kadınlarda ise $5-9 \mathrm{~kg} / \mathrm{m}^{2}$ değerleri normal aralıkta kabul edilmektedir (20). Bu çalışmadaki yağ kütle indeksi değerleri incelendiğinde ise satranç grubundaki kadınların yağ kütle indeksi $(8.0$ kg/ $\mathrm{m}^{2}$ ) normal aralıkta kabul edilirken; erkeklerin değerleri $\left(7.3 \mathrm{~kg} / \mathrm{m}^{2}\right)$ fazla yağlı sinıfındadır (Grafik 2). Literatürde YKİ değerlerinin BKİ değerleriyle ilişkili olduğu bilinmektedir (20). Çalışmamızdaki katılımcılar BKİ değerlerine göre incelendiğinde;18-25 $\mathrm{kg} / \mathrm{m}^{2}$ BKİ aralığındaki Avrupalı kadınlar için verilen 4.9-9.2 kg/m² YKİ aralığında iken, erkekler bu BKİ aralığı için verilen $2.9-6.0 \mathrm{~kg} / \mathrm{m}^{2}$ referans aralığından daha yüksek değerlere sahiptir (20). Yirmi yaş grubundaki Korelilerin (34), YKİ değerleri de (Kadın: $6.0 \mathrm{~kg} / \mathrm{m}^{2}$; Erkek: $4.3 \mathrm{~kg} / \mathrm{m}^{2}$ ) satranç oyuncularının değerlerinden daha düşüktür. Çalışmaya katılan satranç oyuncularının, referans değerlerden ve literatürdeki popülasyonlardan daha yüksek yağ kütle indeksine sahip olduğu görülmektedir.

Toplam ve apendiküler yağsız yumuşak doku kütlesi ise özellikle sarkopeni tanısı koymak amacıyla sıkça başvurulan parametrelerden biridir $(35,36)$. Grafik 2'de kadın ve erkek satranç oyuncularının toplam yağsız yumuşak doku kütlesi indeksine (Erkek: 16.7 kg/ m²; Kadın: $12.5 \mathrm{~kg} / \mathrm{m}^{2}$ ) bakıldığında ise literatürdeki 20 yaş beyaz etnik gruplar için verilen referans değerlerin alt sinırındadır (Referans aralık Erkek:15-25 kg/m²; Kadın:10-20 kg/m²) (18). Satranç oyuncuları, Avrupalı bireylerden daha az (Erkek: $20.3 \mathrm{~kg} / \mathrm{m}^{2}$; Kadın: 17.1 $\mathrm{kg} / \mathrm{m}^{2}$ ) (37) ancak Çinli (Erkek:16.6 kg/m²; Kadın: 13.9 $\mathrm{kg} / \mathrm{m}^{2}$ ) (23) ve İspanyol bireylerle (Erkek: $17.2 \mathrm{~kg} / \mathrm{m}^{2}$; Kadın: $13.5 \mathrm{~kg} / \mathrm{m}^{2}$ ) (26) benzer toplam yağsız yumuşak doku kütlesi indeksine sahiptir. Satranç sporcularının apendiküler yağsız yumuşak doku kütlesi indeksleri de (Erkek: $7.8 \mathrm{~kg} / \mathrm{m}^{2}$; Kadın: $5.4 \mathrm{~kg} / \mathrm{m}^{2}$ ), Koreli (Erkek: $7.4 \mathrm{~kg} / \mathrm{m}^{2}$; Kadın: $5.2 \mathrm{~kg} / \mathrm{m}^{2}$ ) (34) ve Çinli yetişkinlerin (Erkek: $7.3 \mathrm{~kg} / \mathrm{m}^{2}$; Kadın: $5.7 \mathrm{~kg} / \mathrm{m}^{2}$ ) (23) apendiküler yağsız yumuşak doku kütlesi indeksleriyle benzer bulunmuştur.
A Milli satranç oyuncularının vücut yağ yüzdesi ile yağ kütlesi indeksi değerleri referans değerlerin ve literatürdeki verilerin üzerinde iken, yağsız yumuşak doku kütlesi toplam ve apendiküler yağsız yumuşak doku indeksi ise bu değerlerin altında kalmaktadır. Vücut kompozisyonundaki bu durum BKİ değerleri sınırda olmasına rağmen gizli obezite nedeniyle birçok sağllk sorununu beraberinde getirebilmektedir (15). Satranç oyuncularında bu durumun hareketsizlikten kaynaklandığı ön görülmektedir. $\mathrm{Bu}$ nedenle fiziksel inaktivitenin önüne geçilmesi için satranç oyuncularının boş zamanlarında rekreatif etkinliklere katılımları arttırılmalı, antrenörler sağlık ve başarı için düzenli fiziksel egzersizin önemi konusunda oyuncuları bilinçlendirmelidir. Satranç oyuncularının antrenman sürecinde satranç pratiklerinin yanında fiziksel egzersizlere de yer verilmelidir.

Sonuç olarak, bu çalışma satranç sporcularının vücut kompozisyonunu değerlendiren ilk çalışmadır. Aynı zamanda Türkiye A Milli Satranç Takımının vücut kompozisyonuna ilişkin tanımlayıcı veri sağlamaktadır. A milli seviyesindeki takımla gerçekleştirildiği için katılımcı sayısının az olması ve fiziksel aktivite kayıtlarının alınmaması çalışmanın sınırlılığıdır. Satranç bir spor branşı olarak kabul edilmesine rağmen, sedanter bireylerle kıyaslandığında dahi sporcuların daha sağlıksız vücut kompozisyonu bileşenlerine sahip oldukları görülmektedir. $\mathrm{Bu}$ nedenle satranç spor branşları arasında en inaktif spor branşı sayılabilir. $\mathrm{Bu}$ durumun uzun süre devam etmesi, sağlık sorunlarına yol açabileceğinden bu popülasyon fiziksel aktiviteye katılmaya teşvik edilmeli; vücut kompozisyonu açısından belirli aralıklarla takip edilmelidir.

Yazarlık Katkısı - Author contributions: Çalışmanın tasarım: SB, YG, HHT; Çalı̧ma verilerinin elde edilmesi: SB, MMA, YG; Verilerin analiz edilmesi: SA, MMA, CIA, ŞNK; Makale taslağının oluşturulmast: SA, CIA, ŞNK, HHT; İçerik için eleştirel gözden geçirme: $S A, S B, M M A, Y G, C I A$, ŞNK, $H H T$; Yayinlanacak versiyonun son onayl: $S A, S B, M M A, Y G$, CIA, ŞNK, HHT. - Study design: SB, YG, HHT; Data collection: SB, MMA, YG; Data analysis: SA, MMA, CIA, ŞNK; Draft preparation: $S A, C I A$, ŞNK, HHT; Critical review for content: 
SA, SB, MMA, YG, CIA, SSN, HHT; Final approval of the version to be published: SA, SB, MMA, YG, CIA, ŞNK, HHT.

Etik Kurul Beyanı - Ethics approval: Araştırma, Hacettepe Üniversitesi Girişimsel Olmayan Etik Kurulundan (03.11.2020-GO20/1046) alınan etik kurul onayı kapsaminda gerçekleşmiştir. - The research was carried out within the scope of ethics committee approval obtained from Hacettepe University Non-Interventional Ethics Committee (03.11.2020 - GO20/1046).

Çıkar çatışması - Conflict of interest: Yazarlar çıkar çatışması olmadığını beyan ederler. - The authors declare that they have no conflict of interest.

Teşekkür • Acknowledgement: GE Health Care (GE Medical System Türkiye Ltd.) kuruluşuna, CoreScan yazllıminin aktivasyonunu sağladığı için teşekkür ederiz. - We thank GE Health Care (GE Medical System Turkey Ltd.) for providing the activation of the CoreScan software.

\section{KAYNAKLAR}

1. Federation IC. FIDE Laws of Chess taking effect from. Jan 1, 2018. Available at: https://handbook.fide.com/chapter/ E012018 Accessed Nov 23, 2020.

2. Pluss MA, Bennett KJM, Novak AR, Panchuk D, Coutts AJ, Fransen J. Esports: The Chess of the 21st Century. Front Psychol. 2019;10:156.

3. Fornal-Urban A, Keska A, Dobosz J, Nowacka-Dobosz S. Physical fitness in relation to age and body build of young chess players. Pediatr Endocrinol Diabetes Metab. 2009;15(3):177-82.

4. Fornal-Urban A, Keska A, Dobosz J, Nowacka-Dobosz S. Nutritional habits of young chess players. Pediatr Endocrinol Diabetes Metab. 2008;14(3):187-91.

5. Di Renzo L, Gualtieri P, Romano L, Marrone G, Noce A, Pujia A, et al. Role of personalized nutrition in chronicdegenerative diseases. Nutrients. 2019;11(8).

6. Kohl HW, Craig CL, Lambert EV, Inoue S, Alkandari JR, Leetongin $\mathrm{G}$, et al. The pandemic of physical inactivity: global action for public health. Lancet (London. England). 2012;380(9838):294-05.

7. Andreoli A, Garaci F, Cafarelli FP, Guglielmi G. Body composition in clinical practice. Eur J Radiol. 2016;85(8):1461-8.

8. Borga M, West J, Bell JD, Harvey NC, Romu T, Heymsfield SB, et al. Advanced body composition assessment: from body mass index to body composition profiling. J Investig Med. 2018;66(5):1-9.
9. Van Der Ploeg GE, Withers RT, Laforgia J. Percent body fat via DEXA: comparison with a four-compartment model. J Appl Physiol. 2003;94(2):499-06.

10. Morgan SL, Prater GL. Quality in dual-energy X-ray absorptiometry scans. Bone. 2017;104:13-28.

11. Lewiecki EM, Binkley N, Morgan SL, Shuhart CR, Camargos BM, Carey JJ, et al. Best practices for dual-energy X-ray absorptiometry measurement and reporting: International Society for Clinical Densitometry Guidance. J Clin Densitom. 2016;19(2):12740.

12. Helba M, Binkovitz LA. Pediatric body composition analysis with dual-energy X-ray absorptiometry. Pediatr Radiol. 2009;39(7):647-56.

13. Blake GM, Naeem M, Boutros M. Comparison of effective dose to children and adults from dual X-ray absorptiometry examinations. Bone. 2006;38(6):935-42.

14. Santos DA, Dawson JA, Matias CN, Rocha PM, Minderico CS, Allison DB, et al. Reference values for body composition and anthropometric measurements in athletes. PloS ONE. 2014;9(5):e97846.

15. Oliveros E, Somers VK, Sochor O, Goel K, Lopez-Jimenez F. The concept of normal weight obesity. Prog Cardiovasc Dis. 2014;56(4):426-33.

16. Neeland IJ, Ross R, Després JP, Matsuzawa Y, Yamashita $\mathrm{S}$, Shai I, et al. Visceral and ectopic fat, atherosclerosis, and cardiometabolic disease: a position statement. Lancet Diabetes Endocrinol. 2019;7(9):715-25.

17. Direk K, Cecelja M, Astle W, Chowienczyk P, Spector TD, Falchi M, et al. The relationship between DXA-based and anthropometric measures of visceral fat and morbidity in women. BMC Cardiovasc Disord. 2013;13:25.

18. Hinton BJ, Fan B, Ng BK, Shepherd JA. Dual energy X-ray absorptiometry body composition reference values of limbs and trunk from NHANES 1999-2004 with additional visualization methods. PloS ONE. 2017;12(3):e0174180.

19. National Health and Nutrition Examination Survey (NHANES). Dual energy X-ray absorptiometry (DXA) procedures manual. CDC. 2007;3:10-3.

20. Kelly TL, Wilson KE, Heymsfield SB. Dual energy X-Ray absorptiometry body composition reference values from NHANES. PloS ONE. 2009;4(9):e7038.

21. Gallagher D, Heymsfield SB, Heo M, Jebb SA, Murgatroyd PR, Sakamoto Y. Healthy percentage body fat ranges: an approach for developing guidelines based on body mass index. Am J Clin Nutr. 2000;72(3):694-01.

22. Lu YC, Lin YC, Yen AM, Chan WP. Dual-energy $\mathrm{X}$-ray absorptiometry-assessed adipose tissues in metabolically unhealthy normal weight Asians. Sci Rep. 2019;9(1):17698. 
23. Xiao Z, Guo B, Gong J, Tang Y, Shang J, Cheng Y, et al. Sex- and age-specific percentiles of body composition indices for Chinese adults using dual-energy X-ray absorptiometry. Eur J Nutr. 2017;56(7):2393-406.

24. Swainson MG, Batterham AM, Tsakirides C, Rutherford $\mathrm{ZH}$, Hind K. Prediction of whole-body fat percentage and visceral adipose tissue mass from five anthropometric variables. PloS ONE. 2017;12(5):e0177175.

25. Buckinx F, Landi F, Cesari M, Fielding RA, Visser M, Engelke $\mathrm{K}$, et al. Pitfalls in the measurement of muscle mass: a need for a reference standard. J Cachexia Sarcopenia Muscle. 2018;9(2):269-78.

26. Arias Téllez MJ, Acosta FM, Sanchez-Delgado G, MartinezTellez B, Muñoz-Hernández V, Martinez-Avila WD, et al. Association of neck circumference with anthropometric indicators and body composition measured by DXA in young Spanish adults. Nutrients. 2020;12(2):514.

27. Gould H, Brennan SL, Kotowicz MA, Nicholson GC, Pasco JA. Total and appendicular lean mass reference ranges for Australian men and women: the Geelong osteoporosis study. Calcif Tissue Int. 2014;94(4):363-72.

28. Meredith-Jones K, Haszard J, Stanger N, Taylor R. Precision of DXA-derived visceral fat measurements in a large sample of adults of varying body size. Obesity (Silver Spring. Md). 2018;26(3):505-12.

29. Ofenheimer A, Breyer-Kohansal R, Hartl S, Burghuber OC, Krach F, Schrott A, et al. Reference values of body composition parameters and visceral adipose tissue (VAT) by DXA in adults aged 18-81 years-results from the LEAD cohort. Eur J Clin Nutr. 2020;74(8):1181-91.
30. Salamat MR, Shanei A, Khoshhali M, Salamat AH, Siavash M, Asgari M. Use of conventional regional DXA scans for estimating whole body composition. Arch Iran Med. 2014;17(10):674-8.

31. Lees MJ, Bansil K, Hind K. Total, regional and unilateral body composition of professional English first-class cricket fast bowlers. J Sports Sci. 2016;34(3):252-8.

32. Palmer BF, Clegg DJ. The sexual dimorphism of obesity. Mol Cell Endocrinol. 2015;402:113-9.

33. Sari CI, Eikelis N, Head GA, Schlaich M, Meikle P, Lambert $\mathrm{G}$, et al. Android fat deposition and its association with cardiovascular risk factors in overweight young males. Front Physiol. 2019;10:1162.

34. Hong S, Oh HJ, Choi H, Kim JG, Lim SK, Kim EK, et al. Characteristics of body fat. body fat percentage and other body composition for Koreans from KNHANES IV. J Korean Med Sci. 2011;26(12):1599-605.

35. Cruz-Jentoft AJ, Baeyens JP, Bauer JM, Boirie Y, Cederholm T, Landi F, et al. Sarcopenia: European consensus on definition and diagnosis: Report of the European Working Group on Sarcopenia in Older People. Age Ageing. 2010;39(4):412-23.

36. Carvalho CJ, Longo GZ, Juvanhol LL, Kakehasi AM, Pereira PF, Segheto KJ, et al. Body composition indices in Brazilian adults: age-specific and sex-specific percentile curves. Arch Endocrinol Metab. 2019;63(4):358-68.

37. Schautz B, Later W, Heller M, Müller MJ, Bosy-Westphal A. Total and regional relationship between lean and fat mass with increasing adiposity--impact for the diagnosis of sarcopenic obesity. Eur J Clin Nutr. 2012;66(12):135661. 